\title{
The Time of the Tree: Returning to Eden after the Fall in the Cornish Creacion of the World Daisy Black
}

\author{
ADAM: Ty a weall allow ow thryes \\ Pandeth ve a Baradice; \\ En an very prynt leskys \\ Pan ve an noer malegas \\ Der ow oberow ena. \\ (You will see the tracks of my feet, \\ when I came from Paradise, \\ even the very prints burnt, \\ when the earth was cursed \\ through my deeds there.) ${ }^{1}$
}

I

N THE Cornish play Gwreans an Bys (The Creation of the World), Seth travels to Eden to find the Oil of Mercy for his dying father, Adam. ${ }^{2}$ Following the burned pattern of his father's footsteps, Seth reaches the Garden, and the angel guarding Paradise bids him look

I. The Creacion of the World: A Critical Edition and Translation, ed. and trans. Paula Neuss (London: Garland Publishing, 1983), lines 1746-50. All translations given are those of Paula Neuss. I use the original Cornish and a translation for longer quotations and English for shorter quotes (excluding stage directions); further references in text by line numbers.

2. This play has been addressed under a number of titles, including the Creacion of the World (the English title given in the I6I manuscript), and in the Cornish equivalents Gwreans an Bys / Gwryans an Bys. Here, I follow Brian Murdoch in using the first of these two Cornish titles. See Brian Murdoch, "The Cornish Medieval Drama," in The Cambridge Companion to Medieval English Theatre, ed. Richard Beadle (Cambridge: Cambridge University Press, 1994), 2II. 
through the gates. Seth sees a tree with a dried out serpent hanging, dead, in its branches. The angel tells him that this was the tree that bore the forbidden fruit and that the serpent was the creature that deceived Eve. Seth also sees a second tree. The Tree of Life has roots running down into hell, where Seth can see the torment of his recently deceased brother, Cain. But the branches, stretching towards heaven, support a maiden and child. The angel plucks a fruit from this tree and, giving three seeds to Seth, instructs him to plant them in the mouth and nostrils of Adam's body. He promises that the tree growing from these seeds will, in five thousand five hundred years, bear the Oil of Mercy.

The story of Seth's return to Eden originates in early Jewish legend and appears in several forms. For example, in the Greek Apocalypsis Moses, Eve accompanies Seth on his journey, while in the Gospel of Nichodemus Seth goes to Paradise alone. ${ }^{3}$ Translated into the Latin Vita Adae, the narrative was later adapted to include a child in the tree and became popular during the thirteenth and fourteenth centuries in much copied texts such as The Golden Legend and the Latin Legende, which drew further connections between the Tree of Life and the Cross and fused the Oil of Mercy narrative with the popular legends of the Holy Rood. ${ }^{4}$

3. For overviews of the early development of the Seth quest narrative, see Brian Murdoch, The Medieval Popular Bible: Expansions of Genesis in the Middle Ages (Cambridge: D.S. Brewer, 2003), 62-64; Robert Longsworth, The Cornish Ordinalia: Religion and Dramaturgy (Cambridge, MA: Harvard University Press, 1967), 46-52; Esther C. Quinn, The Quest of Seth for the Oil of Life (Chicago, IL: University of Chicago Press, 1962); and Betty Hill, "The Fifteenth-Century Prose Legend of the Cross Before Christ," Medium Aevum 34 (1965): 203-22. See also M. R. James, trans., The Gospel of Nicodemus, or the Acts of Pilate (Oxford: Clarendon Press, 1924), 17, where Seth narrates his journey in order to give hope to the prophets in limbo.

4. Jane A. Bakere claims that the Latin Legende is the closest source material for the tree legend presented in the Ordinalia. She also identifies three other English narrative versions of the Holy Rood Legend: the South English Legendary, the Cursor Mundi, and the Northern Passion. See Jane A. Bakere, The Cornish Ordinalia: A Critical Study (Cardiff: University of Wales Press, 1980), 76-87; Eamon Duffy and William Granger Ryan, ed. and trans., The Golden Legend (Princeton, NJ: Princeton University Press, 20I2), 
As a consequence, texts bringing the Oil and Rood legends together extended the historical range of the narratives, using Seth's return to Eden to look backwards towards the Fall and forwards to the narrative of the Cross.

The combined legends of the Holy Rood and the Oil of Mercy are dramatized in two surviving Cornish mystery plays, where they act as a structuring device weaving events from Hebrew and Christian scriptures into one narrative. ${ }^{5}$ The earliest of these appears in Origo Mundi, the first play of the late fourteenth-century Cornish Ordinalia, which extends the story of the Tree/Cross to incorporate several Old Testament authorities. ${ }^{6}$ Here, the wood of the Cross is traced through the narratives of three Old Testament patriarchs, Moses, David, and Solomon, as well as the miracle of the hapless saint Maximillia, who carelessly sits on the wood, only to find her clothes aflame. Her anachronistic appeal to Christ quenches the flames, only to bring about her death when a sceptical bishop has her stoned for blasphemy. The dramatization of the Holy Rood and Oil of Mercy narratives in the Origo Mundi thus performs in a manner that, Jane Bakere has suggested, reclaims earlier mythology and scripture and uses it to consolidate a Christian polemic:

The combination of the two traditions, linking the archetypal myth of man's search for a saviour with the Christian promise of Redemption through Christ, takes the primitive age-old myth and consecrates it to Christian use. ${ }^{7}$

As such, the Tree of the Ordinalia participates in the same kind of typological processes identified by Roberta Magnani in her essay on

277-84; and Brian Murdoch, The Apocryphal Adam and Eve in Medieval Europe (Oxford: Oxford University Press, 2009), I3I-36.

5. The Oil of Mercy narrative appears in eleven European plays, including the two Cornish plays. See Lynette R. Muir, The Biblical Drama of Medieval Europe (Cambridge: Cambridge University Press, 1995), 71-72.

6. Although MS Bodley 79I, in which the Ordinalia plays survive, shows evidence of fifteenth-century composition, the plays themselves were likely to have been composed and performed in the late fourteenth century. See Brian Murdoch, Cornish Literature (Cambridge: D.S. Brewer, 1993), 4I-42.

7. Bakere, The Cornish Ordinalia, 77. 
Chaucer's The Knight's Tale, typologies that subsume Hebrew figures and histories into the Christian narrative of the Cross. ${ }^{8}$

However, the two legends work somewhat differently in the later Gwreans an Bys, which contains elements that appear to suggest that the wood of the Cross and the Garden in which it grows are continuing to interact, often in a provocative manner, with the times of the play's performance context. The earliest version of the play appears in a I6II manuscript copied by William Jordan. Paula Neuss and Brian Murdoch have convincingly argued that this is a copy of an earlier version that was itself a fair copy of a performance prompt book. ${ }^{9}$ The play itself is believed to have been performed between 1530 and 1550 - some fifty years later than the Ordinalia. ${ }^{10}$ It covers a range of Old Testament and legendary material, including the creation of the angelic orders, the creation of Eden, Lucifer's deception of Eve, the Fall and Expulsion, Cain and Abel, the death of Cain, Seth's return to Eden and the death of Adam, Seth's preservation of the world's history, and the Flood. Jordan's title page states that Gwreans an Bys is "the first daie of playe," and it appears to have been the first of two parts- suggesting that, unlike the threepart Ordinalia, Gwreans an Bys split the salvation narrative between the Old and New Testaments. ${ }^{11}$

Partly because of its incompleteness, partly because it is often viewed as late Cornish drama in decline, and partly because the earliest critical assessments considered it as little more than a reworking of the first part of the Origo Mundi, Gwreans an Bys has received far less attention

\footnotetext{
8. See also Kathleen Biddick, The Typological Imaginary: Circumcision, Technology, History (Philadelphia: University of Pennsylvania Press, 2003), I-20.

9. On the dating of Gwreans an Bys, see Brian Murdoch, "Creation, Fall and After in the Cornish 'Gwreans an bys': Some Comments on a Late Medieval Mystery Play," Studi Medievali 29, no. 2 (1988): 685-705, and the Introduction to Neuss, The Creacion, lxiv-lxix. William Jordan's copy appears in Bodleian MS. 219, and several later copies of the play also survive, with the latest appearing in an eighteenth-century commonplace book.

Io. See Murdoch, "Creation, Fall and After," 690.

II. After the Flood, Noah tells the audience to come again the following day to see redemption granted. See Neuss, The Creacion, lines 2542-46.
} 
than the Ordinalia. The relative lack of work on the play is also related to the fact that it has had the misfortune to slip between the evermore critically fragile late medieval / early modern period divide-is it to be examined as an example of post-reformation religious drama, or as an anachronistic survivor of the devotional dramatic cultures of a medieval Catholic "past"?12 This historical ambiguity has thus led to a certain critical caution in works addressing the play. Yet this sense of historical in-betweeness is not only a product of the critical climate in which Gwreans an Bys has been traditionally received, but also a component of the play's own presentation of its subject matter. I contend that the temporalities operating within and, crucially, upon the play-including those of its biblical and legendary subject matter, those of its midreformation performance contexts, and those of the scribe William Jordan - are reflected in the temporal nature of the play's Garden of Eden. In the Gwreans an Bys, Eden is presented as a place where different moments in biblical and historical time encounter one another, and this amplifies the ability of the Tree of Life to operate within several moments in time at once. This is particularly manifest in three episodes that appear in Gwreans an Bys but not in the Ordinalia. These, first, introduce a gendered dimension to the two trees in Eden, and, second, demonstrate the importance of Seth's ability to follow the tracks of, and preserve knowledge of, the past.

In doing so, I aim to broaden the implications of Robert Longsworth's observation that, while the Origo Mundi of the Ordinalia "unfold[s] a regular and culminative typology" in which the events of the Old Testament provide a series of prefigurations of Christ, Gwreans an Bys views history differently. The later play omits several typologically useful episodes, such as the Abraham and Isaac narrative, and Longsworth claims that this indicates:

I2. Brian Murdoch notes that the play includes "medieval legends dismissed by Reformers," yet claims that "it remains uncertain whether the work retains pre-reformation ideas because the theological changes were not yet known in Cornwall." See Murdoch, Cornish Literature, 75. Later, I argue that the play's introduction of specifically Marian material to the Oil of Mercy narrative suggests a consciousness of, and resistance to, reform. 
the deliberateness with which the episodes were chosen. [The play] presents the patriarchal age not so much in terms of its foreshadowing or prefiguring the life of Christ, but as a period of elemental conflict in which good and evil, creation and destruction, mercy and vengeance struggle to determine the fate of Adam's descendants. ${ }^{13}$

Bearing in mind Longsworth's belief in the "deliberateness" of the play's chosen episodes and the idea that its approach to historical narrative resists both linearity and typological foreshadowing in favor of a series of conflicts, I will examine a sequence of episodes that appear to suggest that different kinds of time are in operation-particularly within the Garden of Eden. These episodes not only engage with religious traditions and devotional practices that were being discredited during the time of the play's performance, but also introduce seeds of Eden's temporal nature into its own production cultures in a manner that holds the potential to be subversive. The Eden of the Gwreans an Bys brings together moments in biblical and early modern time in a manner that Seth perceives as strange, and yet which challenges the audience to make meaning out of them.

\section{Time at the Beginning}

The curious, non-linear times inherent in Gwreans an Bys are in part due to the centrality of Eden in the play and Eden's own role at the heart of Creation. Narratives depicting the beginning of the world necessarily negotiate a slippery path between God's eternal divinity and the temporality constituted in the act of Creation. St. Augustine famously grapples with this in his discussion of the question, "what was God doing before he created the world?" Concluding that there was no time before Creation, Augustine argues that time, and thus human history, began in Creation:

I3. Robert Longsworth, "Two Medieval Cornish Versions of the Creation of the World," Comparative Drama 21, no.3 (1987): 249-58, http://www. jstor.org/stable/4II53289. 
Since, therefore, you are the cause of all times, if any time existed before you made heaven and earth, how can anyone say that you abstained from working? You made time itself. Time could not elapse before you made time. ${ }^{14}$

However, Augustine's conclusion that time simply did not exist before Creation only serves to further underline the disjunction between the ways in which he believed eternal, divine time operated and his own lived experiences of time. ${ }^{15}$ This feeling of disjunction only intensified during the religious debates of the reformation years, where time had long been associated with the postlapsarian world and yet was also seen as redeemable and reclaimable - and as such, an essential part of personal salvation. ${ }^{16}$

Yet neither time nor eternity held fixed meanings. Just as the fifteenth and sixteenth centuries supported a range of ways in which time was experienced, theologized, and quantified, so concepts of eternity demonstrate a similar diverse complexity. ${ }^{17}$ For example, eternity may be presented as the divine experience of the human temporal state (with

I4. Augustine, Confessions, ed. and trans. Henry Chadwick (Oxford: Oxford University Press, 1998), 225-26.

I5. See Wesley Stevens, "A Present Sense of Things Past: Quid est enim tempus?," in Time and Eternity: The Medieval Discourse, ed. Gerhard Jaritz and Moreno-Riaño Gerson (Turnhout: Brepols, 2003), 9-28. During the course of the sixteenth century Augustine's theology was "reclaimed" by various Protestant groups, who cast him as an early Protestant thinker. See Arnoud S. Q. Visser, Reading Augustine in the Reformation: The Flexibility of Intellectual Authority in Europe, I500-1620 (Oxford: Oxford University Press, 2OII), 3-II.

16. See Alec Ryrie, Being Protestant in Reformation Britain (Oxford: Oxford University Press, 20I3), 44I-46.

17. See the different conclusions drawn about medieval time in J. A. Burrow, The Ages of Man: A Study in Medieval Writing and Thought (Oxford: Clarendon Press, 1986); Karen Elaine Smyth, Imaginings of Time in Lydgate and Hoccleve's Verse (Farnham, UK: Ashgate Publishing, 20II); and Carolyn Dinshaw, How Soon is Now? Medieval Texts, Amateur Readers, and the Queerness of Time (Durham, NC: Duke University Press, 20I2). 
God experiencing all events as part of eternity, while humans only experience, and observe, time); it may be conceived of as a concept entirely outside of time; or time and eternity may be constructed as antithetical and moralized concepts belonging to the pre- and postlapsarian worlds. ${ }^{18}$ As a consequence, the Creation scene of Gwreans an Bys-an event where divine eternity and human temporality meet-produces multiple temporal interactions. These result in a number of frictions. For example, the God of Gwreans an Bys appears to partake of a divine eternity operating in all times at once. God's opening declaration that he is "Alpha et Omega" and "Try person in idn dewges" (three persons in one godhead) brings Christian Trinitarian theology into events that constitute the beginning of Hebrew scripture, thus suggesting that, where God is concerned, all times truly are one. ${ }^{19}$ However, God's speeches as he forms the heavens and the orders of angels suggest an alternative experience of divine eternity. Placing repetitive stresses on the words "nefra" (always / eternally / forever) and "pryes" (always) as he ranks his angels, God demonstrates an expectation of eternity as duration that is immediately dismantled by Lucifer's revolt. ${ }^{20}$ Lucifer's rebellion therefore represents a threat, not only because it problematizes the concept of godly foreknowledge, but also because this first act of disobedience deviates from the divine ideal of eternity.

God responds by creating Eden and, in doing so, time itself. Gwreans an Bys is unusual in that it shows God creating Eden and mankind to fill the place left by Lucifer:

DEUS PATER: Gallas Lucifer, droke preve,
Mes an Nef tha dewolgowe.
Ha lemyn un y lea ef
Me a vyn heb falladowe
Un dean formya
In valy Ebron, devery,

I8. See the approaches collated in Jaritz and Moreno-Riaño, Time and Eternity.

19. Neuss, The Creacion, lines I-IO.

2o. Ibid., lines 3I, 44, 59, and 68. 
Rag collenwall aredy

An le may teth anotha.

(336-43)

(Gone has Lucifer, vile snake, out of Heaven to darkness.

And now in his place

Without fail I will

make a man

in the valley of Hebron indeed

readily to fill

the place from which he came.)

$(237-44)$

God's speech wryly anticipates the narrative that follows. The reference to Lucifer as a snake indicates a foreknowledge of Lucifer's temptation of Eve, suggesting that God knows his new human creations will be disobedient. This adds an extra dimension to God's wish that Adam and Eve might take Lucifer's place in heaven. He knows that they will in every sense "fill" Lucifer's place by performing in a similarly insubordinate manner-thus continuing in Longsworth's pattern of elemental conflict. Yet God also knows that Adam and Eve will fill Lucifer's place as it was originally intended. Unlike Lucifer, Adam and Eve's fall from grace will only be temporary, and their redemption means that they and their descendents will partake in the eternal "always" of God's heaven. God's knowledge of the impending Fall and redemption is shared with the Christian audience of Gwreans an Bys that, like God, also knew the conclusion of the salvation story. God and his audience perform as allknowing witnesses to the narrative as it unfolds, yet they are also part of that narrative-God as an actor in a play and as the Creator, and the audience through their knowledge that they, too, are Adam's children and must petition for salvation.

The opening episodes of Gwreans an Bys therefore figure eternity as a state of narrative foreknowledge and as a divine state that is set against diabolical (and later, human) disobedience. Yet it is in the Garden of Eden that time is first acknowledged and ordered, as God blesses the 
things he has made and commands that the seventh day be kept as a day of rest. ${ }^{21}$ While time is initially introduced as quantative-with God using it as a tool of measurement for the calculation of change-God also directs qualitative time by instructing how time is to be observed and experienced. ${ }^{22}$ From this point, time and eternity become increasingly subjective in Gwreans an Bys-being open to the varying experiences and interpretations of not only individual characters such as God and Seth, but also to those of the audience, which brings its own experience of time to the performance. These multiple perceptions of time and narrative become particularly important in the temptation scene, where Lucifer, Eve, and even the serpent ascribe different meanings to questions of time and to language itself.

\section{Eden's First Virgin}

Aggrieved at God's creation of man, Lucifer resolves to tempt Adam and Eve into disobedience. Consistent with medieval tradition, Lucifer aims to deceive Eve rather than Adam, as she is "moy sympell" (more simple-minded). ${ }^{23}$ Due to his new, hideous form, he resolves to enter the body of a serpent. The serpent first appears during Adam's naming of the creatures, where a stage direction describes it as "A fyne serpent made with a virgyn face, and yolowe heare upon her head"(409-Io). The female-faced serpent became a common motif in imagery from the thirteenth century, although it appears less frequently in religious drama. ${ }^{24}$ This idea of the serpent as female enabled an outlet for a multitude of

2I. Neuss, The Creacion, 413-20.

22. I acknowledge the difference between the scientific uses of quantitative time and the qualitative temporality of lived time (time as perceived, experienced, and engaged with by an individual). For discussions of these two kinds of time, see Barbara Adam, Time (Cambridge: Polity Press, 2004) and Anindita Niyogi Balslev and J. N. Mohanty, eds., Religion and Time (Leiden: Brill, I993).

23. Neuss, The Creacion, 475 .

24. Muir, Biblical Drama, 69. The female-faced serpent is found in the Chester cycle and in the Ordinalia as well as in four plays from mainland Europe. 
misogynistic discourses concerning the falsehood of female speech and appearance, and M. C. Bodden notes that "the signifier of snake-as-devil is suppressed and becomes attached to "woman." 25 Readings of the female-faced serpent have traditionally tended to focus on the creature's resemblance to Eve in its receptiveness to Lucifer and in its looks, and images of the temptation scene often play upon this by drawing similar faces for them. However, what is unusual about the serpent in Gwreans an Bys is the fact that it is depicted as an unwilling participant in the temptation of Eve, and this disrupts an uncomplicated visual comparison between the two characters. Furthermore, while Eve's belief that the serpent is an angel stresses its difference from, rather than similarity to, herself, Seth's later vision of the serpent in Eden places it instead in visual comparison to the Virgin Mary.

Lucifer's possession of the serpent's body is arguably one of the more disturbing scenes in Gwreans an Bys. Having chosen the serpent because its face is “за virgin deke pur havall” (5оI) (very like a fair maiden), Lucifer tells Devil Torpen that "Kynna wore hy cowse banna / Me as rowle hy del vannaf" (507-8) (Though she does not know how to speak a bit, / I shall control her as I wish). As the speech preceding this one refers to the serpent as "y" (it) and not "hy" (she/her), Lucifer's speech effectively genders the serpent female at the very moment he plans to assume control over her. This identification of the serpent as female serves not only to confirm that the serpent's feminine face matches its sex, but also to suggest that Lucifer anticipates that, like Eve, all female creatures will be soft-willed and easily molded to his purpose. The serpent's femininity is therefore entwined with the idea that, willing or not, it will be easily controlled, thus reinforcing the connections discussed above between femininity, vice, and weakness. In this, I disagree with Brian Murdoch's argument that:

25. M. C. Bodden, Language as the Site of Revolt in Medieval and Early Modern England (Basingstoke: Palgrave Macmillan, 20II), 47. See also Katie Normington, Gender and Medieval Drama (Woodbridge: D. S. Brewer, 2004), 92-93. 
The serpent as such is merely a serpent, and is most certainly not a female character. It is only an instrument, and we are made well aware that Lucifer is using it. ${ }^{26}$

I argue that not only does Lucifer's speech, with its double emphasis on the pronoun "hy," designate the serpent as a female character, but also that his discussion of the serpent's maidenly looks marks the serpent as a female species. For Lucifer, the face of the serpent, alongside its anticipated submissiveness, determines and fixes its gender.

Moreover, this serpent asserts its status as a character by playing a slightly more complex role than usually appears in dramatizations of the Fall. Despite Lucifer's belief that the serpent will be easily ruled, it initially refuses to be "only an instrument." Lucifer's speech as he forcibly enters the body of the serpent, combined with the stage directions that outline the serpent's failed attempt to escape, reads disturbingly like a form of physical, sexual assault:

LUCIFER: By and by thow shalt se that;

Ha pur uskes gwraf an pratt

Then Serpent, in spyte thy face.

Let Lucyfer com to the Serpent and offer to goe in to her. The Serpent voydeth. And stayeth, and ofereth to go in to ber.
A! Redeball dowethy!
Gorta ha byth thym rowlys!
Gas ve thaentra agye,
Rag ty ny vethys dowtyes
Defran y bosta mar deke.
(You shall see that right away;
and I shall very quickly play the trick
on the Serpent, in spite of [your] face.

26. Murdoch, Cornish Literature, 8I. 
Let Lucifer come to the Serpent and attempt to enter her. The Serpent withdraws. And he detains her, and attempts to enter her.

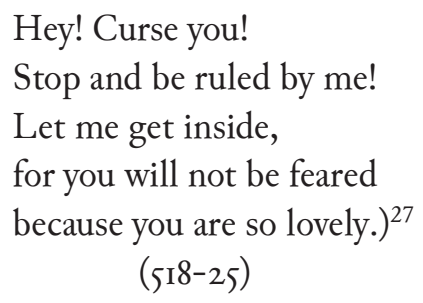

During this moment of violence, Lucifer's language moves between English and Cornish as he addresses a creature that does not command the power of speech or the ability to answer him. ${ }^{28}$ Despite this silence, it is clear from the stage directions that the serpent is entered unwillingly: it tries to escape, is pinned down, and eventually penetrated. The fact that Lucifer tells the serpent he will enter "in spyte thy face" alarmingly juxtaposes his violent entry and the serpent's unwillingness with the creature's maidenly looks-suggesting that, once entered, the serpent can no longer truthfully maintain her virginal exterior. In entering the serpent, Lucifer therefore conceals his own ugliness through the appearance of virginity while simultaneously extending his own deceit to the creature. As a consequence, this scene establishes Lucifer not only as an enemy to humankind, but specifically as an enemy to all female creatures-chiefly because of his ability to perform acts of disobedience through and upon them. Yet unlike Eve, who has the opportunity to repent, albeit belatedly, of listening to Lucifer, this is the only moment of resistance the serpent offers. From this moment, the serpent character's agency vanishes, and it is entirely commanded

27. The square brackets indicate my amendment to Neuss's translation.

28. Gwreans an Bys merges Cornish and English in a similar way to the Latin/English speeches used for the good and bad characters of the morality plays. God's speeches are purely in Cornish, while Lucifer is more prone to using English phrases. A similar patterning of language occurs in the Ordinalia. See Neuss, "Introduction," xxxvi, and David C. Fowler, "The Date of the Cornish 'Ordinalia," Mediaeval Studies 23 (I96I): III, doi: IO.I484/J.MS.2.305962. 
by Lucifer-although it is nevertheless punished by God as though it had been entirely complicit in Lucifer's actions.

This is marked by the fact Lucifer's entry into the serpent gives it a voice even as it disguises his voice:

\section{LUCIFER: Aban oma close entrys \\ Unas sche, a barth agye, Ow voice oll yta changys, A vel maytenth in tevery. \\ (Since I have entered close within you, inside, see, my voice is all changed just like a maiden.)}

$(529-32)$

The idea of the devil speaking through a beautiful, virgin-faced image would have held uncomfortable associations for the audience of Gwreans an Bys. During the programs of iconoclasm between 1536 and 1550 , images, and particularly images of the virgin, were increasingly mistrusted. ${ }^{29}$ While stressing the folly of worshipping manmade, lifeless images, anti-iconographical polemics nevertheless struggled to account for the numerous devotional narratives and beliefs concerning the vivacity of certain images and reports of their ability to speak. This led to suggestions that such accounts were due to the devil entering said images in order to willfully mislead people. For example, James Simpson notes that images of the Virgin Mary were particularly singled out by iconoclasts as instruments of the devil, and, citing Hugh Latimer's demand that the images of the Virgin be burned, he argues that "Latimer's language about these images of the Virgin features all that is idolatrous as simultaneously feminine and diabolic." ${ }^{30}$ Again, the close associations drawn between

29. For an account of iconoclasm under early Henrican reform, see Eamon Duffy, The Stripping of the Altars: Traditional Religion in England I400-I580 (London: Yale University Press, 1992), 379-423.

30. James Simpson, "The Rule of Medieval Imagination," in Images, 
the virgin, the feminine, and the persuasive, diabolical voice operated as warnings against trusting the appearance, if not the substance, of virginity. A loquacious performance by a virgin-faced serpent hanging in a tree during the 1550 O Gwreans an Bys-particularly if the play was performed during the uneasy restitution of Catholicism-would necessarily have borne the marks of a recent iconoclastic past.

Lucifer's ventriloquizing through the serpent's voice also projects forward to the point at which another female voice, that of Eve, takes over his duplicitous speeches as she attempts to persuade Adam to taste the tree's fruit. Yet what is striking about Gwreans an Bys is that, despite his disguise, Lucifer's act of speech signifies that the speaker and the serpent are not "like a maiden"-precisely because it is speech. Katie Normington's study of gender in the mystery plays observes that public, persuasive female speech was considered contrary to the ideal of the silent virgin:

Women's speech was often viewed through the Virgin/Whore dichotomy. The Virgin's silence is contrasted by Eve's loose tongue. It was through language that Eve created original sin. ${ }^{31}$

Once Lucifer enters the serpent and speaks, the serpent is no longer speechless, and thus, no longer virginal. It also becomes less clear whether the serpent is still a female creature. This is reflected in Eve's dialogue, where she first thinks that her companion is not a virgin or a serpent, nor even another female creature, but a male angel. This is partially due to Lucifer's wittily deceptive statement that he has come out of heaven "gans hast pur vras" (557) (in a very great hurry). However, Eve's addresses to the serpent as "dremas" and "sera" (good man / sir), and Adam's later gendering the serpent male when he curses "Ha thaga in weth ganso" (and you too with him) suggests that something other than the serpent's speech betrays the true nature of its situation. ${ }^{32}$ Eve's assumption that her interlocutor is male suggests that, at least in part, she is able to see past the disguise. This apparent gender inconsistency

Idolatry and Iconoclasm, ed. Jeremy Dimmock et. al. (Oxford: Oxford University Press, 2002), 19.

31. Normington, Gender and Medieval Drama, 25.

32. See Neuss, The Creacion, lines 589,600 , and 805 . 
may not have seemed odd for the Cornish audience, and M. C. Bodden argues that:

so encoded in the culture's imagination is the gender of serpent as female that the disjuncture between referencing as male what are clearly images of female serpent-devils on the same page or the same texts is absolutely unproblematic for viewers. ${ }^{33}$

However, this assumption does not obscure the fact that Lucifer's crossplaying performance is only partially successful - he may disguise his face and voice, but cannot obscure his gender. As a consequence, Lucifer's false virgin, hanging in the branches of the Tree of Knowledge and offering its fruit, stands in visual and aural opposition to the silent figure of Mary appearing in Seth's later vision as sitting in the Tree of Life and offering her child to the world.

This difference is underlined by the kinds of temporal understanding that these two figures offer their audience. The dialogue between Eve and the serpent is concerned with questions of eternity. The serpent tells Eve that, if she does not take the fruit, she and Adam will "sertayne venarye / Why a vyth a vell flehys" (653-54) (certain forever / you will be like children). Eve, however, is concerned that they will be sent to Hell forever if they disobey God's commandment (662-64). The fact that Lucifer and Eve speak in terms of eternity rather than time suggests that, before the Fall, the humans in Eden partake in eternal time. After the Fall, however, the figure of Death confirms that they are now subject to temporality and that, had they not sinned, "Mernans ny wressans tastya / Mes in pleasure venarye / Y a wressa prest bewa" (they would not have tasted death / but they would live for ever / in eternal pleasure) (662-64). Adam and Eve's loss of eternity is thus coupled with their loss of Paradise. However, before they leave, Adam begs God for the Oil of Mercy. His hope of eventual redemption therefore already resists the restraints of linear temporal decay by anticipating an event later in the narrative that will effectively reverse Lucifer's deceit. It is this Oil of Mercy - and the promise of a return to eternity-that is offered by Eden's second Virgin in a tree.

33. Bodden, Language as the Site of Revolt, 47. 


\section{Burned Footprints}

As he grows older, Adam becomes weary, and eventually he begs his son, Seth, to travel east to Eden and seek the Oil of Mercy. Still in the first age of the world, Seth inhabits a time in which humans still have the ability to travel to Eden, and he follows the footprints his parents left burned into the soil. ${ }^{34}$ Journeys towards Eden were often characterized in earlier medieval literature as involving movements through time as well as space. Discussing the Book of John Mandeville, Carolyn Dinshaw claims that "to travel east in this book is an asynchronous activity: it is to travel back in time." ${ }^{35}$ In Gwreans an Bys, Seth's journey also marks a travelling back in time:

SETH: Me a weall ooll tryes ow thas, An lead ve tha Baradice.

Hema ew marrudgyan bras;

An noer sure ny sowenas

In for may wruge eave kerras.

(I see a print of my father's foot, which will lead me to Paradise.

This is a great marvel;

the ground has certainly not flourished

In the path where he went.)

(1762-66)

Although Seth's journey occupies a mere three stanzas, it traverses great distances in space and time. Furthermore, while the temporalities examined by Dinshaw in John Mandeville are chiefly concerned with charting an individual's experience of geographical time travel, the journey of the Cornish Seth also encourages the play's audience to trace the prints of

34. The withered footprint motif appears in the Ordinalia and Gwreans an Bys. For possible sources, see Murdoch, Cornish Literature, 52, and Kari Sajavaara, "The Withered Footprints on the Green Street of Paradise," Neuphilologische Mitteilungen 76 (1975): 34-38.

35. Dinshaw, How Soon is Now?, 75. 
their own times by recollecting the penitential performances and popular spiritual journeys of the recent Catholic past.

Seth's journey along his father's prints provides an opportunity to reflect upon how his parents' sin has disfigured the landscape, as well as upon his own woe at being excluded from Paradise. In doing so, his journey constitutes a form of a pilgrimage - partaking in the belief that the act of travelling to a certain place atoned for sin. Seth's vision at the gates of Eden offers a glimpse, if not the fulfilment, of the salvation to come, suggesting that his journey contributes towards a kind of penance for his parents' Fall. Moreover, the journey itself performs as an essential part of the play's salvation narrative because it enables the wood of the Cross to enter the world. Bakere's discussion of the narrative appearing in the Ordinalia notes that while Adam's footsteps act as "a physical witness to $\sin$... they also show the way back to Paradise ... in this context, they become a symbol of penitence and expiation."36 The journey undertaken in the Gwreans an Bys, however, extends beyond Seth's own experiences in Eden. If charred prints leading back into the past find the promise of future salvation, then the inclusion of this journey in the play, and the manuscript within which it is contained, also holds the subversive potential to direct the audience's attention back to the penitential practices of the past.

The pilgrimage of contrition is a particularly apt model for Seth's journey towards an Eden that is both a physical place and a participant in the eternal, heavenly realm. Eamon Duffy explains that "the primary purpose of pilgrimage had always been to seek the holy, concretely embodied in a sacred place, a relic, or a specially privileged image." ${ }^{37}$ The Eden of Gwreans an Bys is presented as a fixed, accessible place located in the valley of Hebron, and yet, for Seth, it is also not of the Earth. It is a sacred place and a historical place; a place formerly inhabited by Seth's parents, yet now a place defined by exclusion-Seth may walk to the gates, but not enter them. This gives Seth's vision of Eden a liminal quality that is not apparent during the earlier scenes of the play. Dinshaw engages with Eden's liminality in John Mandeville by arguing that it

36. Bakere, The Cornish Ordinalia, 79.

37. Duffy, The Stripping of the Altars, I9I. 
commands a temporality that is inaccessible: "Eden ... has a beautiful but inaccessible temporality all its own: Eden is still on the map but it nonetheless forever lost to humans." ${ }^{38}$ However, in Gwreans an Bys, Seth does briefly access this time through his vision of the two trees and, moreover, carries part of that time away with him in the three seeds that will become the Cross. The Garden may be enclosed, but it is not entirely closed, and Seth's visual access to Eden and the angel's gift of the seeds offer him an entirely new way of experiencing time.

\section{Eden: A “Thin” Place}

Before bidding Seth to look through Eden's gates, the angel warns him of the "strangnes" (strange) (I80o) things he will see there. Seth sees two trees; one holding the dead serpent, and one stretching between the two unearthly realms of heaven and hell. Seth's first account of what he can see deals with the subject matter that is the least temporally strange. The serpent hanging in the Tree of Knowledge is dry and dead:

SETH: Me a weall sure un gwethan,

Ha serpent unhy a vadn

Marow seigh hy a valsa.

(Surely I see a tree

and a serpent up in it.

It would seem to be dry dead.)

(I8०8-Іо)

The angel explains that this tree bore the forbidden fruit and that the serpent was the one the devil entered to tempt Eve. The dryness of the serpent therefore confirms the journey Seth has already begun into his parents' past. Things have changed in Eden. The time that has passed between the Fall and Seth's return is marked on the body of the serpent, and Seth makes no mention of the beautiful, virginal face that was so central to its role in the temptation narrative. Instead, the serpent, like the declining Adam, has come to symbolize the consequences of the

38. Dinshaw, How Soon is Now?, 76. 
Fall-death and decay. As such, it is the only thing in the Garden of Eden to be subject to the linear passage of time.

While the dead serpent might have been something that Seth, aware of his parents' history, could have reasonably expected to see in Eden, the second tree, the Tree of Life, is indeed participating in temporal strangeness. This tree moves through space and time in a way the world outside Eden does not; compressing past, present, and future into one visual experience. The tree's roots run down to a hell in which the recently slaughtered Cain dwells in pain, while the branches stretch all the way up to heaven, where sit a maiden and a child. The wood of the Tree of Life thus connects different moments in biblical history and space, linking close and distant moments in Seth's past, present, and future into one organic existence. These moments are also arranged spatially. Hell contains the recent past, with the deceased Cain lying there in torment. Heaven contains a vision of the distant future, projecting forward to the new wood that will be generated from the tree: wood that will bring together Old and New Testament times into one Christian narrative of salvation.

Such incidents of temporal conjunction have recently been granted a great deal of attention in medieval and early modern studies and have facilitated a range of discourses on multi-temporality, palimpsested time, topological time, and temporal collapse. ${ }^{39}$ One strand of this work concerns temporal collapse provoked by the visual encounter of an "anachronic" material artefact that brings incidents from the object's past, present, and, occasionally future, together. ${ }^{40}$ Yet while Seth's act

39. See for example Jonathan Gil Harris, Untimely Matter in the Time of Shakespeare (Philadelphia: University of Pennsylvania Press, 2009); Leo M. Carruthers, Raeleen Chai-Elsholz, and Tatjana Silec, eds., Palimpsests and the Literary Imagination of Medieval England (New York, NY: Palgrave Macmillan, 20II), and the discussion of theorizing non-linear temporalities as "queer" in Elizabeth Freeman et al., "Theorizing Queer Temporalities: A Roundtable Discussion,” GLQ: A Journal of Lesbian and Gay Studies I3, no.2-3 (2007): 177-95.

40. See Alexander Nagel and Christopher S. Wood, Anacbronic Renaissance (New York, NY: Zone Books, 2oro), 32: "visual artefacts collapsed past and present with an ease and suddenness that no text could match." 
of looking does indeed bring different events into one moment, what is experienced in Eden is the impression of thinness between moments in time rather than the complete simultaneity of all times. By "thinness," I mean that, in the Tree of Life, moments in time grow closely together, yet are not collapsed into one state, partially obscured by one another, or placed in hierarchy as they are in models of temporal palimpsest or collapse. Nor is time folded, as it is in discourses of temporal topology. Instead, temporal thinness mirrors the way in which the Garden of Eden operates spatially, as a place between the heavens and the earth. ${ }^{41}$ The body of the Tree of Life presents elements from Hebrew and Christian narratives to the viewer as though the time between these events is thin-almost translucent-and yet the audience and the angel who tells Seth that the Oil of Mercy will not arrive for another five thousand, five hundred years remain conscious that that time is still there between these events. This thinness between the spaces of heaven and earth and between events in biblical history presents the viewer with an image of respite interrupting the play's episodic patterning of disobedience and punishment.

\section{Eden's Second Virgin}

At the center of Seth's vision are the maiden and child sitting in the Tree of Life:

SETH: Hag in tope an keth wethan

Me a weall un maythethe wheake

Ow setha, in pur sertan, Hag in y devra flogh teake,

Der havall thym indella.

4I. My inspiration for the concept of "thin" times and places comes from a comment made by Rev. George MacLeod of the Iona Community, Scotland, that Iona is a "thin place-only a tissue paper separating the material from the spiritual." See Jane Bentley and Neil Paynter, Around a Tbin Place (Glasgow: Wild Goose Publications, 20II), 7. I contend that the Eden of Gwreans an Bys is another such "thin" place. 
(And in the top of that same tree

I see a sweet maiden

sitting, most certainly,

and a lovely child in her bosom,

really like myself thus.)

(I834-38)

Although Seth's speech does not identify the figures, the stage directions call them "Mary the Virgyn [and] her sonn Jesus," suggesting that the identity of the two figures would have been visually obvious to his audience. ${ }^{42}$ The appearance of the Virgin, as well as a baby, in the Tree of Life is unique to Gwreans an Bys, and this vision presents its viewers with a particularly loaded image given that the play was performed at a time when Marian devotion (and particularly iconography) was discredited, as mentioned above. Mary's appearance in Gwreans an Bys has consequently met with bafflement in a variety of studies, with some works reading her as being little more than a signifier that the child in the tree is Christ and others claiming that her presence is a deliberate inclusion by a Cornish community of theatre-makers who wished to articulate their resistance to the reformation. ${ }^{43}$ Given the centrality of the Virgin in a tree that represents the entire history of the Christian world, the latter theory is more plausible, as Mary's presence resists the iconoclastic aim to, as James Simpson argues, "distance the past from the present as rapidly and decisively as possible." ${ }^{44}$ In this, Gwreans an Bys operates as part of a culture of politicized drama that Greg Walker has called the "arts of resistance." Examining sixteenth-century political and politicized dramas, Walker notes that, while the performance

42. Here, I disagree with Neuss's theory that the Eden vision would not have been physically represented on stage but rather communicated through Seth's speeches. Given that the temptation scene is staged, it is probable that the Tree of Knowledge and the serpent would have remained in the Eden playing-space until Seth returned to Eden. On the play's staging, see Neuss, "Introduction," lx-lxi.

43. See Murdoch, Cornish Literature, 90, and Neuss, "Introduction," lxxii-lxxiii.

44. Simpson, "The Rule of Medieval Imagination," II. 
of new dramas risked prosecution if they were deemed too politically disruptive, "revising an old play in new circumstances can have as powerful contemporary resonances as performing a new work commissioned for the purpose." 45 The revision of biblical, and particularly legendary, material in Gwreans an Bys therefore had the potential to be especially powerful as it promoted the retention and promotion of narratives and images that were coming under censure. The maiden that Seth sees sitting "most certainly" in the tree thus acts in defiance of the increasing insecurity of her images during and after the reformation.

In addition to this, the Virgin also works to transform the times operating within Eden. Her presence in the Garden is not entirely surprising given that, as other papers in this volume have shown, medieval artworks had often situated the mother of Jesus in imaginary garden spaces (see, for example, (see, for example, this issue, Magnani, ıo6, fig. 3 and II4, fig. 4). As the three other essays in this volume also demonstrate, these images rested on the interplay between a blooming yet enclosed garden space and Mary's virginal yet fruitful condition. Miri Rubin has argued that such depictions commonly contrasted Mary with Eve:

Reflection on Mary in gardens sometimes brought to mind the primal scene of Eve's sin. . . thinking of Mary and Eve in a single frame amounted to telling the whole Christian story: of Incarnation and promise of salvation. ${ }^{46}$

However, in Gwreans an Bys, Mary's position in the tree means that she is chiefly paralleled with the serpent and not within the traditional Avel Eva polemic. This may well have been emphasized by the visual spectacle presented to the audience. While Paula Neuss argues that the virgin face of the serpent is "a grotesque parody of the Virgin Mary sitting in the top of the flourishing Tree of Life," I contend that they perform as negative images of one another, with Mary's child becoming the antidote to the

45. Greg Walker, Reading Literature Historically: Drama and Poetry from Chaucer to the Reformation (Edinburgh: Edinburgh University Press, 2013), I9.

46. Miri Rubin, Mother of God: A History of the Virgin Mary (St Ives: Allen Lane, 2009), 3II. 
serpent's apple. ${ }^{47}$ The Cornish Mary is not the first virgin in a tree, even if she is the only true virgin in the tree.

Mary's presence in the Tree of Life also alters the gender dynamic of this scene. Seating Mary in the tree and at the very center of Eden secures her place at the heart of the salvation narrative and of biblical time. This version of the Oil of Mercy narrative skews the Christocentric temporalities of the Holy Rood legends, which place Christ at the center of time, by projecting forward to the suffering of his mother. ${ }^{48}$ Sitting among boughs that already bear the seeds of the Cross, the Virgin's presence directs viewers to Mary's grief at the future Crucifixion. While the fruit of the Tree of Knowledge brings death to Adam and Eve, the seeds carried from the Tree of Life foreshadow the death of Mary's child. This in turn influences the way in which Seth is presented in the Gwreans an Bys. Seth initially has an affinity with the child in the tree, saying that it is "Der havall thym indella" (really like myself thus) (I838). The reading of Seth as a proto-Christ figure is not unusual, and he is one of a number of Old Testament figures frequently appearing in religious drama as prefiguring Christ. ${ }^{49}$ However, the presence of Mary and the serpent in the neighboring tree interrupts this idea by instead aligning Seth with Eve.

Throughout the course of the play, the serpent and Mary hang in their respective trees and offer the viewer a form of divine understanding. The serpent offers the fruit of death and the knowledge of good and evil, while Mary offers her child - the fruit of salvation and hope of eternal life. This means that Seth stands in Eve's place as an onlooker and as a recipient of the second tree's fruit. Their resemblance may well have been underlined by the play's staging. If a visual comparison is made between the positioning of the serpent and Mary, then a similar comparison might be drawn between the positioning of Eve and Seth. Both characters are situated as trying to make meaning out of the trees

47. Neuss, "Introduction," xxxii.

48. See Balslev and Mohanty, Religion and Time, 9: "for Christianity time and eternity meet, and it is at this meeting point that Jesus announces his presence."

49. See Rosemary Woolf's discussion of Noah in The English Mystery Plays (London: Routledge and Kegan Paul, 1972), I33. 
and the figures in them, and the similarity between their positions would have been enhanced by the probability that the two characters were played by male actors. ${ }^{50}$ The inverse paralleling of Mary and the serpent therefore precipitates further paralleling in which Seth's role as a proto-Christ is diminished in favor of his role as the opposite of and, in part, atonement for, Eve.

\section{Burying Books}

While Seth gains a certain level of knowledge through his encounter with the fruit of the Tree of Life, he leaves Eden with that knowledge incomplete. Unlike Eve, Seth is content with the limited information that the angel reveals to him-that the second tree is the Tree of Life and that its fruit will one day bear the Savior. He does not seek to extend his knowledge beyond divinely appointed parameters. As a consequence, while the Tree brings moments in Christian time together for the play's audience, who know the narrative that is to follow, it does not offer a vision of eternity to Seth. Eden's engagements with time and eternity are therefore experienced differently by those inside and outside the playing space: Seth can see, but cannot fully understand, while his audience can see and understand.

Eden thus remains partially closed to Seth in a way it is not to his audience. But something out of the Garden-a part of its temporally thin nature-does leave Eden with him. When Seth takes three seeds from the Tree of Life into the world and plants them in Adam's body, he acts as an agent in the Garden's bringing together of times. As a consequence, Eden's time begins to restructure the times outside its gates. The trinity of seeds binds together Hebrew and Christian narratives,

50. While neither the Ordinalia nor Gwreans an Bys give information about their cast members, enough is known about other dramatic conventions to infer that the Cornish plays were likely to employ crossplaying. See Richard Rastall, "Female Roles in All-Male Casts," Medieval English Theatre 7, no. I (1985) and Robert L. A. Clark and Claire Sponsler, "Queer Play: The Cultural Work of Crossdressing in Medieval Drama," New Literary History 28, no. 2 (1997): 319-44, http://www.jstor.org/ stable/20057418. 
while also suggesting a circularity that is reminiscent of God's eternal "Alpha et Omega." While medieval devotional literature celebrated the fact that mankind fell and was redeemed by a tree, the Gwreans an Bys takes this one cycle further: Adam's dead body physically becomes that tree, thus bringing the eternal out of the temporal. ${ }^{51}$ Adam's soul, however, goes to limbo-essentially falling out of time during the 5,500 years it takes for the Oil of Mercy to be delivered. As a consequence, Adam and his descendents only access eternity through their experience of temporality - the waiting for redemption. ${ }^{52}$ Like the Tree of Life, the seeds released from Eden enable human bodies and souls to connect and partake of several moments in time.

I have shown that the two trees of Gwreans an Bys have the ability to work between narrative pasts, presents, and futures in a manner that resists the supersessionary reformist dialogues of the mid sixteenth century. However, this kind of temporal thinness may also be glimpsed in the ways in which the play and its I6I manuscript operate in relation to time. I will therefore conclude by addressing a short episode from the end of Seth's narrative. Following a brief diversion in which Enoch is taken up to heaven and Jared warns the audience not to emulate Adam's disobedience, Seth, who has miraculously outlived several generations of prophets, predicts the destruction of the world. In order to avoid the peril of mankind's continued breaking of God's commandments, Seth resolves to preserve the history of the world and founds the world's first library (217I). As Seth does not know whether the impending destruction will take the form of fire or flood, he and Jared deposit duplicate

5I. See Duffy and Ryan, The Golden Legend, I7: "Since the first man had brought death into the world by means of wood, a tree, it was appropriate that the Son of man should banish death by dying on a cross of wood."

52. It also introduces an idea of the afterlife that merges the Catholic idea of a purgatory-like waiting place between heaven and hell with the Protestant stress on the need for contrition and personal redemption. On the effect of changing theologies of contrition and the afterlife on sixteenthcentury dramatic performance, see Stephen Greenblatt, Hamlet in Purgatory (Princeton, NJ: Princeton University Press, 200I), IO-46. 
records inside pillars of brick and marble in the hope that one of them will survive.

SETH: Scryffes yma thym pub tra

A thallathfas an bysma,

May fova leall recordys

A vyns tra es ynna gwryes.

Four bookes to be shewed.

An leverow y towns y omna -

Why as gweall, wondrys largya;

Ha pub tra oll in bysma

Skryffes yma in ryma.

Dowt navons y ankevys.

(I have had everything written down

from the beginning of this world,

so that it be truly recorded

about everything that has been done in it.

Four books to be showed

Observe the books here

amazingly big, you see them,

and everything in all this world

is written down in these:

lest it should be forgotten.)

(2172-8o)

The two pillars constitute a visual image that echoes that of the two trees in Eden: they are two upright columns each containing a specific kind of temporal, historical knowledge. Moreover, the fact that Seth is fearful that the early history of the world might be forgotten, and also that he relies upon books, rather than stone or clay tablets, to record this history, transposes Seth's act of temporal resistance and desire to retain and record the past to the play's own time. ${ }^{53}$ With his big books, Seth

53. The Vita Adae tradition does not use books or pillars. Instead, Eve asks Seth to inscribe tablets of stone and clay so that one copy will survive. See 
adopts a method of historical preservation that would have resonated with the play's dramatic and literary audiences.

The Gwreans an Bys was performed at a time when English mystery drama was being legislated out of existence, suggesting that the play, like Seth's book-burying, participated in a form of cultural preservation. A 1602 account from Richard Carew's Survey of Cornwall gives evidence that Cornish drama based on "scripture history" continued to be performed into the early seventeenth century, drawing crowds from "many miles off." ${ }^{4}$ Since Cornish scriptural drama continued well after the last recorded performance of English mystery drama, it is possible that Gwreans an Bys was itself performed as a means of preserving dramatic material that was being increasingly seen as endangered. As demonstrated above, the presence of apocryphal narratives, Marian iconography, and references to religious practices such as pilgrimage in a play that was performed until the late 1550 os produce deliberate anachronisms-working contrary to the political and religious changes that aimed to consign narratives that had no scriptural basis to the past. This is not merely an act of pleasurable nostalgia: it also operates as an act of defiance. Their inclusion, coupled with Seth's act of literary preservation, indicates an attempt on behalf of the 1550 playmakers and of Jordan's I6II copy to resist consigning the narratives and practices of the old faith to the past by drawing together the knowledge of times threatening to disappear. A play about the interlinked nature of Christian time might thus be extended to the challenge-riddled fabric of its audience's times.

This drive to preserve also extends to language in which the play is written. William Jordan's I6I copy of the play was created some sixty years after the 1549 Cornish Prayer Book rebellion opposed the replacement of Latin with English in religious practice. This rebellion protested against the enforcement of the Church of England's first Book of Common Prayer in Devon and Cornwall, which were areas of Roman Catholic loyalty. The Cornish also campaigned for a Prayer Book in their own language, as many could not read English, thus conflating

\footnotetext{
Murdoch, Cornish Literature, 93.

54. Richard Carew, Survey of Cornwall (London, 1602), reproduced in Neuss, The Creacion, 239-40.
} 
the survival of Catholic religious practices with the survival of Cornish itself. ${ }^{55}$ If so, then a performance of a mystery play in Cornish constitutes a means of retaining elements of Catholic devotion while keeping the Cornish language in community use. ${ }^{56}$ This partly explains the mixture of English and Cornish in the text of the Gwreans an Bys. It appears that, by the late $1550 \mathrm{O}$, written English was deemed the most appropriate language to communicate stage directions, suggesting that it was either the most readily understandable or that the directions were newer than the Cornish text. In performance, however, English was chiefly given to characters such as Lucifer and thereby presented as a morally dubious encroachment on the Cornish language spoken by God. Jordan's I6II copy of the play text, and the fact that it was considered important enough to be reproduced several more times, suggests that the play, like Seth's books, participates in an attempt not only to preserve the languages and devotional practices of the past, but to recognize their ability to release meaning for future generations.

While Seth's journey to Eden constitutes a journey backwards in time, his actions on returning project forwards into future times that exceed the conclusion of his own narrative. More things than seeds are brought out of the Garden. Gwreans an Bys enables feminized elements of medieval religious devotion to enter a post-reformation culture in which the female was becoming less visible even as it performs stories censured as outdated and erroneous in a language similarly threatened with disappearance. As a consequence, Eden, like the linguistic, devotional, and dramatic cultures Gwreans an Bys sought to preserve, remained a place human beings might still travel to-if they only remember to follow their forebearers' footprints.

University of Hull

55. See Vivian Salmon, Language and Society in Early Modern England: Selected Essays 1982-1994 (Philadelphia, PA: John Benjamins Publishing, 1996), 93, and A. S. D. Smith, The Story of the Cornish Language (Camborne: Camborne Printing and Stationery, 1947), 8.

56. On the role of drama in preserving Cornish, see Longsworth, The Cornish Ordinalia, 4-5. 